\title{
SOSYAL MEDYA OYUNLARINDA GERÇEKLİK OLGUSUNUN YÖN DEĞISTTIRMESI: SMEET OYUNU ÖRNEĞİ
}

\author{
İpek SUCU ${ }^{1}$
}

\begin{abstract}
ÖZET
Günümüzde hızla yaygınlaşan sanal dünya, insanlar arasındaki sosyal mesafeyi yok eden ve çift yönlü iletişimi gerçekleştiren bir evredir. Bir tür sosyal aktivite haline gelen sosyal medya oyunları, bir yandan sosyal mesafeyi azaltırken diğer yandan da sosyal teması yok etmektedir. İnsanlığın esas gereksinimi olan iletişim, gerçek mekânlarda doğaçlama olarak yüzyüze ve olağan hızla gerçekleşirken, günümüzde artık sanal mekânlarda kurgulanmış olarak çok hızlı gerçekleşmektedir. Bu kurgu dünyası gerçekliğin yerine geçerek iletişimde algılanan gerçeklik olgusunu değiştirmiş̧ir. Ortaya çıkan yeni gerçeklik anlayışında kültür, tüketim ve iletişim biçimleri sanal ortamlarda tüketilir hale gelmiştir. Yeni sanal tüketim biçimleri, gerçek mekânlarda yakın mesafede dokunulabilir temasa olan ihtiyacı giderek daha fazla azaltmaktadır.

$\mathrm{Bu}$ çalışmada sosyal medya oyunlarının insanların varoluşsal gerçekliklerinin yönünü sanal ve yapay görsel bir evrene yöneltmesi sonucu söz konusu oyunların iletişimde ya da iletişim sürecinde meydana getirdiği değişimler iletişim kuramları ışığında sosyal zaman-mekân ve sosyal mesafe-temas üzerinden tartışılmıştır. Bu bağlamda konuyla ilgili literatür taraması yapılmışır. Literatür kapsamında öncelikle sosyal oyunların nasıl bağımlılık yaratan bir sosyal aktiviteler bütünü haline geldiği incelenmiş̧tir. Bu incelemenin ardından söz konusu oyunlar aracıllğıyla algılanan gerçeklik olgusunun sosyal zaman-mekân ve sosyal mesafe-temas yoluyla ne tür bir değişime uğradığı tartı̧ılmış̧ır. Son bölümde ise konun örneklendirilmesi amacıyla "smeet oyunları" monografik örnekleme tekniği aracılı̆̆ılla analiz edilmiştir.
\end{abstract}

Anahtar Kelimeler: Sosyal Medya Oyunları, İletişim, Sanallaşma, Tüketim, Gerçeklik.

\section{CHANGE OF DIRECTION OF THE REALITY FACT IN THE SOCIAL MEDIA GAMES: SMEET GAME SAMPLE}

\begin{abstract}
In our day, the rapidly expanding virtual world, the social distance between people and destroying a universe that performs bi-directional communication. The social games that have become some kind of a social media games decreases the social distance but kills the social contacting. The main requirement of the mankind, communication occurs in an ordinary speed face-to-face spontaneously in real places but in our days, it occurs in a very fast already fictionalized virtual places. This fictional world has taken the place of reality and changed the reality fact that is perceived in communication. In the new reality understanding, cultural, consummation and communication figures is being consumed in the virtual environments.
\end{abstract}

${ }^{1}$ İpek Sucu. Doktora Öğrencisi, Maltepe Üniversitesi İletişim Fakültesi, İletişim Bilimleri Doktora Programı. ipek_isilay@yahoo.com 
As a result of the social media games directing the existential realities of the humankind to a virtual and artificial visual universe, there has been some changes in the communication, and these are discussed in the light of communication theories on the subjects of social time-place and social distance-contact in this work. There will be a literature search in this manner. In the literature, the subject of how the social games became addicting social activities was examined first. After this examination, the phenomenon of the social time-space reality is perceived through games and social distance was changed by what kind of through-contacts are discussed. On the last chapter "smeet games" through monographic sampling technique has been analyzed.

Key Words: Social Media Games, Communication, Virtualization, Consuption, Reality.

\section{Giriş}

İnternetin günümüzde hızla gündelik yaşama egemen olması internetin kullanımını vazgeçilemez hale getirmiştir. İnternet kullanımını bağımlılık haline getiren en önemli nedenlerden biri sosyal medya oyunlarıdır. Sosyal medya oyunlarının sosyal ağdaki pek çok kişiyle iletişim kurmayı ve bu kişilerle sanal ortamda oyun oynayabilmeyi sağlaması çok sayıda kişiyi bilgisayar ekranına bağlamaktadır. Sosyal medya oyunları iletişim kurma biçimlerini değiştirdiği gibi tüketim alışkanlıklarını da değiştirmektedir. Bireyler gerçek hayatta gerçekleştiremedikleri, lüks sayılabilecek pek çok hayali sosyal medya oyunları aracılığıyla gerçekleştirmeye çalışmaktadırlar. Sosyal medya oyunlarında tüketim de sanallaşmaktadır. Oyun kullanıcıları her türlü iletişim, tüketim ve sosyal aktivite ihtiyacını sosyal medya oyunlarıyla karşılamaya başlamıştır. Oyun kullanıcıları sanal mekanları zamanın hızla ve eğlenceli olarak akıp gittiği, insanlar arasındaki sosyal mesafenin azaldığı ve sosyal temasın arttığı bir yer olarak görmektedirler. Bu durum iletişimin yüzyüze beden dili ve temas aracılığıyla ve de birebir canlı olarak görme yetisiyle gerçekleştirilmesi gereksinimini azaltmaktadır. Temassal iletişimin azalması iletişimde gerçeklik olgusunun yön değiştirmesi sorununa yol açmaktadır. Bu sorun kapsaminda sosyal medya oyunlardan "smeet" sosyal medya oyunu monografik örnekleme tekniği ile analiz edilecektir. Monografik örnekleme tanıtıcı araştırmalar kategorisi içerisinde yer almaktadır. Tanıtıcı araştırmaların amacı genellikle durum ya da olayların genel niteliklerini belirleyebilmektir. Monografik örnekleme olay ve olguları olduğu gibi araştırmaktadır (www.cymg.meb.govtr/modulerprogramlar/ arastirma_teknikleri.pdf). 
Ele alınmış olan smeet sosyal medya oyunu örnek olay monografisidir. $\mathrm{Bu}$ çalışmada sosyal medya oyunlarından biri olan smeet oyununda gerçeklik olgusunun nasıl dönüştüğünün "işlevsellik ve bağımlılık", "temas-mesafe" ve "zaman-mekan" ilişkileri kapsamında incelenmesi amaçlanmaktadır. Smeet oyununun örnek olarak seçilme sebebi, diğer birçok sosyal medya oyunlarında gözlemlenebilen pek çok sosyal ve sanal içeriği bir araya toplayan geniş kapsamlı oyunlardan biri olmasıdır. Smeet oyununda sanal tüketimin oldukça fazla olması, sanal sosyal aktivitelere ilginin yoğun olması, sanal iletişimin yadsınamaz derecede etkin kullanılması bu oyunun seçilmesi açısından önem taşımaktadır. Bu çalışmada öncelikle sosyal medya oyunları hakkında genel bir literatür çalışması yapılmıştır. Daha sonra örnek olarak ele alınan smeet sosyal medya oyununun özelliklerinin neler olduğu ayrıntılı olarak incelenmiş ve oyun niteliklerinin kullanıcıların iletişim biçimlerinde ve sosyal aktivitelerinde ne tür dönüşümlere ve yeniliklere yol açtığının analiz edilmesi amaçlanmıştır. Analiz sürecinde literatür araştırmasından faydalanılmasının yanı sıra, olay ve olguları daha net araştırabilmek için 1 yıl süresince günde 4 saat oyun içerisinde tüm aktivitelerde bulunularak gözlem yapılmış, oyun özellikleri ve etkileri hakkında ayrıntılı bilgiler alabilmek için 150 oyun kullanıcısı ve 12 oyun yöneticisi ile sosyal ağda çevrimiçi olarak iletişime geçilerek derinlemesine görüşme yapılmıştır. Ayrıca smeet oyunun gözlemlenmesinde 500 kullanıcı profili, 1000'in üzerinde kullanıcılar arasındaki iletişim diyalogları ve 55 farklı oyun odası incelenmiştir. Elde edilen bilgiler aracılığıyla smeet sosyal medya oyunun işlevselliklerinin neler olduğu, kullanıcılar arasında nasıl bağımlılığa dönüştüğü, iletişimde zaman-mekan ve temas-mesafe ilişkilerinin gerçeklik olgusu bağlamında nasıl dönüşümler yaratmış olduğu analiz edilmiştir.

Sosyal medya oyun ağları içerisinde kullanıcı sayısı hızla artan smeet sosyal medya oyununun zamanla işlevselliğinin bir bağımlılık haline dönüşmesi, kullanıcıları gerçek yaşamsal mekanlarda bulunmaktan ve gerçek temassal iletişimden uzaklaştırmaktadır. Smeet sosyal medya oyununun iletişimsel dönüşümlerinin neler olduğu ve gelecekte ne tür etkilerinin olabileceğinin analiz edilmesi bu konuda iletişimsel değişimlerin nasıl daha iyi bir düzeye getirilebileceğinin düşünülmesi açısından yararlı olacaktır. 


\section{Sosyal Medya Oyunlarında İşlevsel Özelliklerin Bağımlılığa}

\section{Dönüşümü}

Sosyal medya oyunlarının kullanılmasına olanak sağlayan internet, bireylerin mekandan ve zamandan bağımsız olarak enformasyon sağlayabilecekleri ve iletişim kurabilecekleri bir ortam sağlamaktadır. Bireyler televizyon ve radyo gibi kitle iletişim araçlarının karşısındaki pasif konumlarını internet ile aktif bir konuma çevirme imkanına sahip olmuşlardır. Bireyler televizyon ve radyo kitle iletişim araçları ile tek yönlü bir iletişim içerisindedirler çünkü kitle iletişim aracından gelen iletişime karşıllk olarak cevap verememektedirler. İnternet çift yönlü iletişimi olanaklı kılarak iletişime aynı anda cevap verebilmeyi yani çevrimiçi iletişime geçebilmeyi sağlamaktadır. İnternet üzerinden işlevsel etkileşim, kullanıcıların iletişim sürecindeki egemenliğine vurgu yapmaktadır (Timisi, 2003: 132). İnternette özellikle sosyal medya oyunları kullanıcılara forumlarda, chat odalarında, kişisel web sayfalarında istediklerini dile getirebilme, tartışabilme, bilgi edinebilme olanağı vererek iletişimi çift yönlü olarak kullandırmaktadır. Birbiriyle çevrimiçi iletişim kuran kitleler "sanal topluluk" olarak tanımlanmaktadır. Sanal topluluklar arasında ortak ilgiler paylaşılmakta ve dinamik ilişkiler kurulmaktadır. Bu toplulukların içine coğrafi olarak her ülkeden birey katılabilmektedir (Sicilia ve Palazon, 2008: 257). Sosyal ağ siteleri, kullanıcıların uzun süredir yüzyüze görüşemedikleri bireylerle sanal ortamda görüşebilme imkanını tanımaktadır (Boyd ve Ellison, 2007). Çevrimiçi iletişimin kaliteli hizmet sunması, konfor sağlaması ve düşük maliyetli olması sosyal paylaşım alanlarına katılımcıları arttırmaktadır (Miller vd., 2009: 305-322).

Sosyal ağın ilk oluşumu şirketlerde kurulan yerel ağ bağlantıları ile sağlanmıştır. Kurulan yerel ağ içinde mesajlaşan çalışanlar ve e-posta grupları ilk çevrimiçi sosyal ağ örnekleri olmaktadır. Daha sonra Bloglar, Wikiler, Twitter ve Facebook gibi sosyal ağ siteleri gibi sosyal işbirliği, iletişim ve bilgi paylaşımı sağlayan çevrimiçi sanal topluluklar oluşmuştur. Hızla artan sosyal ağ siteleri sağladıkları olanaklar sebebiyle zamanla vazgeçilemez olmuştur. (Fu vd., 2007: 675). Sosyal ağ siteleriyle kişisel web sayfaları, sohbet odaları, internet forumları, elektronik tartışma grupları, web toplulukları ve bloglar gibi ara yüzler oluşturularak çoklu iletişim kurulabilmektedir (Sicilia ve Palazon, 2008: 257). Sosyal ağ siteleri, 
insanları sanal mekanda bir arada toplayarak sanal sosyal bir çevre oluşturmaktadır. Oluşturulan bu sanal sosyal çevreler bireylerin günlük yaşamsal aktiviteleriyle benzerlik göstermektedir (Ploderer vd., 2008: 333).

McLuhan’ın “Araç mesajdır” görüşüne göre, kitle iletişim araçları sosyal etkiler oluşturmada kayda değer bir şekilde etkilidir. McLuhan'a göre, sosyal etkiler kişilere bir takım yeni değerler katması ve bu yeni kültürel değerlere adapte olmasıyla gerçekleşmektedir. Bu düşünürün, "Küresel Köy” kuramına göre, yeni medya ileri teknolojiye ulaşarak toplumlar arasında sınırları kaldırarak dünyanın her köşesinde teknolojiyi kullanan herkesin, coğrafi sınırlar ve sınırlamalar olmaksızın diledikleri kişiyle iletişim kurabilmesini, haberleşebilmesini ve bilgi paylaşımda bulunabilmesini sağlayacaktır (McLuhan, 2001: 32). Günümüzde McLuhan'ın da öne sürdüğü gibi hiçbir coğrafi sınır tanımadan kolay ve hızlı bir şekilde iletişim kurmak mümkün olmuştur. Bu sınır tanımaz iletişim kültürler arasında da etkileşimi arttırmıştır. Bu kurama günümüzde kültürel ve iletişimsel etkileşimi büyük ölçüde arttıran sosyal medyayı da ilave etmek gereklidir. Sosyal medya iletişimi sanal bir evrene taşıyarak sanal sosyal bir kültürün oluşmasına meydan vermiştir. Sosyal değişim kuramına göre, gerçek sosyal hayat aktiviteleri yerini köklü biçimde farklı teknolojilere dayanan yeni kurum ve sosyal yapılara birakmaktadır (Han, 2010).

Sanal evren, gerçek yaşamda gerçekleştirilebilmesi için hem maddi hem de manevi çaba harcanması gereken pek çok aktivitenin yaşanabildiği bir ortamdır. Bireylerin hayallerinde kurdukları kültürel ve sosyal çevrelerini kendilerinin yaratabilmeleri sanal ortamın çekiciliğini arttırmaktadır. (Croteau ve Hoynes, 2003: 307). Sosyal medyanın bir uzantısı olan sosyal medya oyunlarında kullanıcılar kendilerini sanal bir yapaylıkta yeniden üretmek için takma bir ad seçerek kendilerine kullanıcı kimliği oluşturmaktadırlar. Sosyal medya oyun kullanıcıları kendilerini tanımlamada kendileri için uygun gördükleri bir kimlik modeline bürünebilmektedirler. Oluşturdukları kimlikler tanınan ünlü bir kişi olabildiği gibi kendilerince tasarladıkları bir model de olabilmektedir. Oluşturulan kullanıcı kimlikleri istenildiği zaman farklı kimlikler şeklinde yeniden oluşturulabilmektedir. Bir oyun kullanıcısının birbirinden farklı kullanıcı isimleri ve kullanıcı profilleri bulunabilmektedir. Kullanıcıların kendi kimliğine bağlı kalmaması, istedikleri 
kimliklere bürünebilmesi sosyal medya oyunlarına olan ilgiyi canlı tutmaktadır (Gürhani, 2004). Kimliğin muğlak ve kaygan bir terim olduğunu söyleyen Buckingham, özellikle son yıllarda bu kavramın çok farklı amaçlarda kullanılmakta olduğunu ileri sürmektedir (Buckingham, 2008: 1). Bireyler, kimliklerini arzu ettikleri şekilde konumlandırmak için oyundaki giyinme tarzlarından iletişim kurma biçimlerine, boş zaman aktivitelerine ve müzik tarzlarına değin farklı materyal ve kültürel öğelere başvurmaktadırlar (Binark, 2005: 75). Modern kimliğin konumu, bireylerin meslekleri, kariyerleri çerçevesinde oluşurken, postmodernitede ise kimlik görsellik, imaj ve tüketime dayanan boş zaman aktiviteleri çerçevesinde oluşmaktadır (Kellner, 2001: 207). Sosyal medya oyunlarında kullanıcılar kimliklerini özgürce üretmekte ve kendilerini oluşturdukları kimlikler bağlamında istedikleri biçimde yaşayabilmektedirler (Funk, 2005: 62-63).

Kimliklerin karşılıklı iletişim aracılığıyla biçimlendiğini söyleyen Poster'a göre, birey gerçek kimliğini diğer oyunculardan gizleyerek ismini, cinsiyetini, toplumsal rol ve statüsünü değiştirerek sahte kimliklerle hiç tanımadığı kişilerle iletişimde bulunabilmektedir (Timisi, 2003: 171-172). Bu şekilde farklı kimliklere bürünebilme iletişimde gerçeklik sorununa işaret etmektedir. Sürekli değişen kimlik modellerine sahip kişilerle iletişimde bulunmak sahte ilişkilerin oluşumuna meydan vermektedir. Kimliklerde gerçekliğin yok olması, sanal iletişimde yapay gerçekliklerin giderek daha fazla kabullenilmesine neden olmaktadır. Oynanılan oyunlar, özdeşleşilen karakterler sayesinde kişilerin modelleme gereksinimlerini de karşılamış olmaktadır. Sosyo-kültürel açıdan ele alındığında, kişinin oyun oynadığı süre içinde kendi yaşam koşullarından uzaklaşmakta, kendini oynadığı oyunun bir parçası olarak hissetmekte ve kendine bambaşka bir kimlik kazandırabilmektedir.

Sosyal medya oyunları yaşamı sadece belli bölümleriyle yansıtmaktan ibaret değildirler. Artık gerçek yaşamdaki tüm aktiviteler oyuna dahil edilebilmektedir. Günümüzde sosyal medya oyunları bilgi edinme, eğlendirme, kamuoyu oluşturma gibi kitle iletişim araçlarının işlevselliklerinin giderek gerçeklikten uzaklaşmasına yol açmaktadır. Bireylerin kendilerine sahte bir kimlik oluşturarak iletişim kurdukları kişileri aldatabilmesi, yayınlanan haberlerin doğrululuklarının yeterince sorgulanmaması, yanlış haberler karşısında da güçlü kamuoylarının oluşturulabilmesi 
sosyal medya oyunlarının gerçek olayları ve kişileri saptırmasına yol açmaktadır. Gerçekliğin sorgulanma gereğinin hızla esnemesi sanallığın gerçekliği kalın bir perdeyle kapatmasına yol açmaktadır.

Sosyal medya oyunları günümüzde bir tüketim mecrası olmaya başlamıştır. Sanal topluluklar, bu mecrada mal ve hizmetleri kullanmaya, denemeye ve tavsiye etmeye yönlendirilebilmektedir (Sicilia ve Palazon, 2008: 257). Sosyal medya oyunları yeni müşteriler çekmek için çevrimiçi ilişkiler ile pazarlama faaliyetlerinde bulunmakta ve mevcut müşterilerle de satın alma yönelimlerini artırmaktadırlar (Fox, 2009: 100). Modern insan yaşamını giderek daha fazla kendi ihtiyaçlarını karşılayacak ve refahını arttıracak tüketimlere yönelerek geçirmektedir (Baudrillard, 2004: 89). İnternetin ve sosyal ağların kullanımının artmasıyla birlikte dijital pazarlama tüketimde haz almayı sağlayan bir mecra olmuştur. Sosyal medya oyunlarında satılan ürünler yalnızca sanal ortamda kullanılabildiği için tüketim sanal tüketimdir. Bu sanal mecralarda sanal yaşam aktiviteleri için her türlü ürün pazarlanabilmektedir. Sosyal medya oyunlarında kullanıcı kimlikleri için kıyafetler, mobilyalar, arabalar, hayvanlar, bitkiler, oyun odaları gibi pek çok sanal ürün oyunun bir parçası olarak satılmaktadır. Sanal ürünleri tüketmek sanal evrende güç, zenginlik ve prestij gösterisi haline gelmiştir. Debord (2006: 40)'a göre, gösteri “sayıları giderek artan imaj-nesneleri doğrudan doğruya biçimlendiren ileri bir iktisadi sektör olarak güncel toplumun esas üretimidir." Sosyal medya oyunlarında tüketilen ürünler ihtiyaçları karşılamaktan ziyade imaj doyumunun karşılanması amacıyla yapılmaktadır. Sanal tüketim gösteri toplumunun meydana gelmesinde önemli bir aracıdır. Tüketimin kullanıcıların birer imaj gösterisi haline dönüşmesi gelecekte tüketimin gösteri amaçlı yapılmasının giderek artacağını göstermektedir.

Sosyal medya oyunlarındaki sanal ortamlar kurgu evrenin bir yansımasıdır. Bireyler gerçek yaşamda gerçekleştiremedikleri birçok eylemi bu mecralarda gerçekleştirebildikleri için sanal dünyanın gönüllü birer bağımlısı olmaktadırlar. Sosyal medya oyunları öncelikle bir alışkanlığa sonrasında ise bağımlılığa dönüşmektedir. Oyun bağımlılı̆̆ı, bireyleri gerçek yaşam aktivitelerinden ve temassal yüzyüze iletişimlerinden uzaklaştırmaktadır (Griffiths, 2010). Sosyal medya oyunlarının giderek bağımlılık haline gelmesi bireylerin davranışlarını da 
etkilemektedir. Sosyal medya oyunlarında şiddet içerikli oyunlara maruz kalmak ve ya bu oyunları oynamak ile kişilerin agresif davranışlar göstermesi arasında anlamlı bir ilişki bulunmuştur. Söz konusu oyunlar kişilerdeki agresyonu geçici olarak arttırdığı gibi toplum yanlısı davranışları da azalttı̆̆ı görülmüştür. Haftada yirmi saatten fazla oyun oynayan kişilerde negatif duygu durumu, depresyon semptomları ve insan ilişkilerinde bozulmalar bulunmuştur (Parker, 2009). Bu durum bilgisayar ve video oyunu bağımlılı̆̆ psikoloji kuramcısı B. F. Skinner'ın “Operant Şartlanma” kuramı ile de açıklanabilmektedir. Skinner'e göre, bilgisayar oyunlarının bağımlılık haline gelmesinde "ödül” etkili bir araçtır. Ödül, oyun oynayan her kişi ve her oyun için farklı anlamda ve amaçta olabilmektedir (Ryan, 2007). Kullanıcılara verilen ödüller kullanıcılar için prestij, itibar, zenginlik anlamlarını taşıyarak sanal ortamda kolayca arkadaş edinmenin bir yolu olmuştur. Puanı ve ödülleri yüksek olan oyun kullanıcılarının diğer kullanıcılara göre daha arkadaşlık listesinde daha fazla sayıda arkadaşı olduğu görülmektedir. Birey, oyunun sunduğu yeni dünya karşısında refleksif olarak etkilenmekte ve oyuna yönelmektedir. Oyun oynama sirasinda ve sonrasında da fizyolojik bir rahatlama hissetmektedir. Oyun oynandiktan sonra hissedilen bu tip rahatlatıcı duygular, oyun oynama davranışının tekrarlanarak bir alışkanlık ve sonrasında da bağımlılık haline gelmesine yol açmaktadır (www.epsikoloji.com). Oyunlara bağımlı olma durumu bireylerin hayatlarını kontrol edememesine sebep olabilmektedir. Bu kişiler zamanlarının büyük kısmını bilgisayar başında geçirdikleri için yüzyüze sosyal ilişkileri ve gerçek yaşamdaki sosyal aktiviteleri azalmaktadır. Söz konusu bu oyunların temelde eğlendirme, boş zamanları değerlendirme, arkadaş edindirme ve karşılıklı enformasyon paylaşımı gibi işlevsel özellikleri zamanla boş zamanların büyük bir çoğunluğunu işgal eden sanal sosyal aktiviteler bütünü halinde bir bağımlılığa dönüşmüştür.

\section{Sosyal Medya Oyunlarında Temas-Mesafe Dönüşümü}

Kullanıcılar, sosyal medya oyunlarının dijital aktivitelerini gerçek dünyadaki bir takım deneyimlerle bütünleştirmektedirler. Bireyler günlük deneyimlerini ve fikirlerini sosyal ağlarda özgürce paylaşabilmektedirler. Bireyler ve örgütler, sosyal medya ağlarına gereksinim duyduklarında zaman sınırı olmaksızın her an katılabilmektedirler. Sosyal medya ağlarında bireyler iletişim kurabilmek için 
mesajlarını karşı tarafa iletirler ve karşılığında geri bildirim alırlar. Bu şekilde kurulan iletişimde bilgi ve paylaşım akışı çift yönlüdür (Çankaya, 2010). Sosyal ağ kuramına göre, insanların çoğunluğu sosyal iletişim anlamda birbirlerine bağlıdır. Bireyler birbirleriyle bağlantı kurabilmek için çeşitli kitle iletişim araçlarını kullanmaktadırlar. Günümüzde yeni medya yüzyüze iletişimde olduğu gibi çift yönlü bir iletişim sağlamaktadır. Sosyal medya aracılığıyla kurulan iletişim coğrafi uzaklıktaki insanları birbirine yakınlaştırarak mesafeleri azaltmaktadır (Neumann ve Hogan, 2005: 472). Bu değişim insanlarla karşılıklı iletişimi kolaylaştırmıştır (Mohamed, 2007, 103). Sosyal medya ve sosyal medya oyunlarıyla iletişim kurmak bireylere yüzyüze iletişimde olduğu gibi çift yönlü bir iletişim imkanı sağlasa da kurulan bu iletişimde yüzyüze iletişimden farklı olarak gerçek anlamda beden dili ile temassal bir yakınlık sağlanamamaktadır. Sosyal medya oyunları iletişim için gereken mesafeyi kısaltmasına rağmen, gerçek anlamda bedensel bir temas sağlanamadığı için aslında gerçek temassal mesafe artmaktadır. Yüzyüze iletişim bireylerin birbirlerine dokunma, mimik ve jestlerde bulunma gibi imkanları temassal olarak sağladığı için iletişimde gerçek anlamda karşılıklı bir duruş, tartışma veya anlaşma sağlanabilmektedir. Yüzyüze iletişim, iletişimde devamlılığı sağlamaktadır. Sosyal medya ile iletişimde ise istenildiği zaman iletişim ağını kesebilme söz konusu olduğu için iletişim her zaman sürekli değildir.

Sosyal medya; televizyon, radyo ve gazete gibi geleneksel kitle iletişim araçlarını kapsayan iletişim yetkinliği konusunda da dönüşüm yaratmıştır. Medyanın iletişim yetkinliği üzerine farklı görüşler mevcuttur. Bourdieu iletişimsel yetkinlikte sosyal statünün, ekonomik koşulların, bireylerin öğrenim düzeylerinin önemli olduğunu belirtmektedir (Bourdeu, 1997, 54). Günümüz sosyal medyasında yaratılan gerçek dışı kimlikler nedeniyle söz konusu bu ilişkilerin çok da öneminin kalmadığı görülmektedir. Sosyal medya oyunlarına iletişim yetkinliği açısından bakılırsa sosyal sınıfın ve ekonomik koşulların yerine edinilen arkadaş sayısı ve imaj ve prestij geçmiştir. Sosyal medya oyunları içerisindeki farklı sanal mekanlarda her türlü yaşam tarzını yaşamak mümkün hale gelmiştir. Örneğin; bir tarla ya da çiftliği ekip biçmek, havuzlu bir villada davetlileri ağırlamak, bir uçakta parti verilebilmek ya da sanal evlerin önünden roket dahi firlatabilmek olanaklı hale gelmiştir. Sanal 
dünyanın sınır tanımazlığının hızla artması gelecekte kullanıcıların isteklerinin de sınır tanımayacağını göstermektedir. Luhmann, bireylerin gerçekleştirmek istedikleri eylemlerini başkalarıyla birlikte yapmak zorunda oldukları için iletişim kurduklarını savunmaktadır (Luhmann, 1995: 113). Sosyal medya oyunlarında da bu savın gerçekleşmeye devam ettiği görülebilmektedir. Bu oyunlarda bireyler oyunları yalnız oynamaktan ziyade birden fazla kişiyle çevrimiçi olarak oynamak istemektedirler. Oyun görevlerinin yerine getirilmesi için bir grup kurmak gerekli olmuştur. Grubu kurabilmek içinse diğer kullanıcılara ihtiyaç duyulmakta ve bu ihtiyaç da iletişimin kurulmasını mutlak hale getirmiştir. Medya tüketicisi açısından yeni medyayı eski medyadan farklı kılan en önemli özellikler yeni medyanın kontrol ve seçim olanağı sağlamasıdır (Macmillan, 2006: 208).

Kişisel ve ticari iletişimler çevrimiçi olarak hızla sanal gerçeklikte ilerlemektedir (Mislove vd., 2007: 31). Bireyler sosyal medyadaki sanallık içersinde bireyler kendilerine gerçekmiş gibi yaşanılan bir çevre yaratmakta ve bu çevre onlar için ikinci bir yuva haline gelmektedir. İnternetteki paralel dünya, günlük hayattaki ikinci bir gerçeklik haline dönüşmüştür. Gerçek yaşamdaki ilişsiler bütünü - aile, arkadaşlar, tanıdıklar, iş arkadaşları, amirler, komşular vs. - sosyal medya aracılığıyla sanal gerçekliğe aktarılmaktadır. İletişimin sanallaşması ve gerçek temassal iletişimin önüne geçmeye başlaması bloglar, Twitter, gibi sosyal medya ağları aracılığıyla oluşmuştur.

İletişim teknolojileri gerçek dünyayı teknolojik olarak donatılan bir üst-gerçekliğe dönüştürmektedir. İletişim teknolojileri kişiler arası ve toplumsal ilişkilerde temel çerçevede bir rol üstlenmektedir. İletişim ağlarında çok sayıda enformasyona maruz kalındığı halde bu enformasyonların çok daha az anlamı bulunmaktadır. Yeni medya teknolojisinin gelişmesi ve ilerlemesi toplumsal örgütlenmenin ve üretimin yerini almıştır. Bu durum yeni bir simülasyon çağının içerisinde olunduğunu göstermektedir (Baudrillard, 1991: 22,23). Günümüzde bireyler artık güvenilir bilgi, kişisel yaratıcılık ve değer kaynaklarının bir yana itildiği bir ă̆ toplumunda yaşamlarını sürdürmektedirler (Taatila, 2006, 312). Bu durumun neden olduğu gösteri dünyası, gerçeğin kaybolduğu bir evrene dönüşmüştür. Yüzyüze iletişimde yüzyüze olma durumu, yani oradalık mevcut iken 
sanal iletişimde gerçek mekan paylaşımı olmaksızın ses, görüntü ve yazı aktarımı sayesinde iletişim kurulmaktadır (Işık, 2000: 34). Bu gerçeğin yerine geçen sahte evrende yalnızca enformasyon, eğlence, imaj ve politika simülasyon içerisinde değildir, iletişim de bir simülasyon içerisindedir. Sosyal medya oyunları günümüzde yalnızca yoğun enformasyon nedeniyle simülasyon içerisine girmemektedir. Gündelik yaşamın getirdiği yoğun yaşamdan bir kaçış olarak görülmeye başlanan sosyal medya oyunları sağladığı eğlence imkanı, yeni kimliklere bürünme, çok sayıda arkadaş edinme, sosyal prestij ve güç kazanma bireyleri simülasyon evreni içerisinde sanal bir dünyaya itmektedir. Bu evrende iletişim gerçek sosyal temastan uzaktır. İletişimin ekranın ardından yazı ile kurulması iletişimde gerçek dokunsal teması ve canlı olarak görmeyi simgelere indirgemiştir. Sosyal medya oyunlarda kullanıcıların kendilerini tanımlamak için oluşturdukları profillerinin çizgi karakterler şeklinde olması görselliğin animasyon ile giderek daha fazla yapaylaştığını göstermektedir. Bu sahte kurgu dolu dijital dünyada ekranın ardından temas sadece sözcüklere, yapay görüntülere ya da kameranın ardından oluşan seyirlik imgelere dönüşmüştür. Sosyal oyun ağlarının, teması bu şekilde dönüştürmesi coğrafi mesafeleri yakınlaştırırken gerçek temassal mesafeleri uzaklaştırmaktadır.

\section{Sosyal Medya Oyunlarında Zaman-Mekân Dönüşümü}

Bilişim ve iletişim teknolojileri zaman, mekân ve coğrafi uzaklık faktörlerinden kaynaklanan sınırlılıkları ortadan kaldırmayı; ses, görüntü, hareketli görüntü ve veri biçimindeki tüm enformasyon aktarımlarını tek bir ağ içinde bütünleştirmeyi sağlayacak bir biçimde gelişmiştir. Sosyal medya oyunları kullanıcılarına farklı yaşam tarzlarını sunacak, çok sayıda arkadaş edindirecek ve çeşitli sosyal aktivitelere dahil edecek çeşitli sanal mekanlara sahiptir (Büyükbaykal, 2008. 40-50). Sosyal medya oyunları bireylerin yalnızlıklarını gidermeye çalışacakları ve kendilerine bir sığınak olarak görecekleri sanal ve büyülü bir ortam sunmaktadır (Yüksel, 2006: 22-26).

Sosyal medyanın sosyal ilişkiler üzerine etkisi hususunda çeşitli görüşler savunulmaktadır. Bazı ütopyacı düşünürlere göre, sosyal medya bireylere yeni ve etkin bir iletişim sağlamaktadır. Beck, sosyal medya aracılığıyla kurulan iletişimin, ifade edilmek istenen duyguları daha kolay ve rahat bir şekilde iletilmesini 
kolaylaştırdığını savunmaktadır. Bu durum çoklu iletişimsel ilişkilerin sosyal bağlarını geliştirip kuvvetlendirmektedir (Beck, 2004: 3). Bu görüşe karşı çıkanlar ise sosyal medyanın bireyleri sosyal topluluklardan ve ailelerinden uzaklaştırdığ düşüncesindedirler (Wellman vd., 2001: 436-438). Onlara göre sosyal medya kullanımı sosyal bağları azaltmakta ve sosyal yalnızlığı daha fazla artırmaktadır (Sanders vd., 2000). Sosyal medya ve sosyal medya oyunlarının bireylerin iletişim kurmalarında zaman-mekan açısından kolaylık sağladığı yadsınamamaktadır. Ancak bu iletişim zamansal ve mekansal olarak sanal bir uzlamdadır. Sanallığın hakim olduğu bir iletişimde bireylerin tümüyle yalnızlıklarını aştıklarını ve sosyal olduklarını söyleyebilmek mümkün değildir.

Sosyal medya, yalnızca kamuoyu oluşturmada haber ve bilgiyi taşıyan bir araç olarak değil, üzerinde kamusal ilişkilerin gerçekleştiği bir alan olma özelliği ile de dikkat çekmektedir. Bu durum sosyal medyanın, kamusal katılımın oluştuğu bir mekan olma özelliğini göstermektedir. Sosyal medya ile sivil toplumun genişlemesi ve küreselleşmesi ile "kamusal alan kavramı dönüşüme uğramakta; paylaşılan mekan anlamında değil, paylaşılan sorunlar ve ortak çıkarlar etrafinda bir araya gelmenin araçları olarak yeni teknolojiler önemli bir nitelik kazanmaktadır" (Timisi, 2003:207).

Gündelik yaşamda zamanın kullanımı, bireylerin önemli bir planlama zorunluluğudur. Yirmi dört saatlik zaman dilimi içerisinde tüm yaşamsal aktivitelerde ve toplumsal etkileşimlerde bulunmak için zaman parçalanmaktadır. Marx'a göre, "boş zamanı olmayan, tüm yaşamı uyku, yemek ve benzeri şeylerin getirdiği fiziksel kesintiler dışında kapitalist için çalışmakla geçen kişi, yük hayvanından bile aşă̆ıdır. Kendi dışına yönelik zenginlik üreten bir makinedir yalnizca" (Marx, 1997: 27).

(...) elektronik teknolojisinin, tüketim ekonomisinin ve kitle kültürünün koşulladığg bir süreçte çocukluk, sektöre dönüşmüştür. Çocukluğun ipleri artık ne çocukların ne de yetişkinlerin, fakat çocukluğu sermaye yapmış bu endüstrinin elindedir. Yetişkin kıyafetli, ağır makyajlı çocuklar, doğum yapan ya da çocuk aldıran Barbie bebekler, yanı başımızdaki kanlı savaşların animasyonu olan Counter Srikes vb. bilgisayar oyunları; Power Rangers çeteleri, Pokemon canavarları... Hepsi bu endüstrinin 
ürünleridir. Ve bu endüstri aracıllğıyla yaşanan, çocukluk değil yetişkinliğin minyatür halidir (Atay, 2005: 18).

Veblen'in "gösterişçi tüketim” anlayışıyla çakışan boş zaman anlayışı, sanal bir zenginlik, prestij ve güç kaynağı olarak modern zamanda ortaya çıkmaktadır. Kitleler boş zamanlarını sosyal medya oyunları oynayarak doldurmaya başlamıştır (Juniu, 2000: 69). Sosyal medya oyunları boş zamanlarda sosyal aktivitelerin sanal olarak yapılmasında kayda değer bir yer edinmeye başlamıştır. Bu oyunların hem boş zamanları değerlendirme imkanı sunması hem de eğlenmeye olanak sağlaması oyunların kitleler tarafından beğenilmesinde öncelikli nedenler olmaktadır. Ancak günümüzde boş zamanların büyük bir çoğunluğunun ekranın karşısında sosyal medya oyunları ile harcanması bireyleri bu sanal dünyanın gönüllü kölesi durumuna getirmektedir. Oyun başında geçirilen vakitlerin tüm boş zamanları doldurmaya başlaması gerçek yaşamdaki sosyal aktivitelere yer ayırmaya engel olduğu gibi radyo, televizyon ve gazete gibi diğer kitle iletişim araçlarına dahi zaman ayıramamaya neden olmaktadır. Kendilerini sosyal medya oyunlarında vakit geçirmekten alıkoyamayan kullanıcılar aynı zaman içerisinde birden fazla aracı kullanmaya başlamışlardır. Bu durum çeşitli araçlar arasında çoklu/paralel kullanımı doğurmuştur. Çoklu/paralel ortam bütün farklı ortamları bir araya toplama yetisine sahiptir. Metin, durağan görüntü, hareketli görüntü, ses gibi ortamların birliktelikleri bu kullanımı meydana getirmektedir (Dilmen, 2007: 115). Önceleri yalnızca bilgisayarın kendi içerisine sahip olan bu yetiler günümüzde tüm kitle iletişim araçları arasında kullanılır duruma gelmiştir. Bu duruma, bir yandan bilgisayarda oyun oynarken, diğer yandan sosyal ağdaki kişilerle iletişim kurmak ve aynı anda bir yandan da televizyonda dizi seyretmek örnek verilebilir. Böylece üç yeti bir arada kullanılmış olmaktadır.

Sosyal medya oyunları boş zamanların eğlenceli olarak değerlendirilebildiği aktivitelerinden biri olarak sosyalleşme olgusuna katkıda bulunmaktadır (Komito ve Bates, 2009: 233). Sosyal medya oyunları bireylere ihtiyaç duydukları eğlenceli vakitler geçirebilme, arkadaş listesine eklenen kişilerle sohbet edebilme, sanal tüketim yapabilme ve gerçek yaşamdaki pek çok sosyal aktivitenin sanal olarak gerçekleştirilebilmesi imkanını sağlamaktadır (Balcı ve Ayhan 2007: 175). Günümüz 
sosyal medya oyunlarının en önemli özelliği yalnızca oyun oynama işlevi ile sınırlı kalmayıp gerçek yaşamın yaşanabilir pek çok öğesini söz konusu oyunlara dahil etmektir. Tüm sanal sosyal aktiviteler sosyal medya oyunları içinde genellikle 3D animasyonlu mekanlarda yapılabilmektedir. Sanal mekanların 3D olması gerçek mekalara daha yakın bir görünüm taşıdığı için etkileyiciliği de daha fazla olmaktadır. Poster'a göre (1997: 206-210), internet, bir iletişim aracı olmanın ötesinde bir toplumsal mekandır. $\mathrm{Bu}$ mekan yeni toplumsal ilişki biçimlerinin yaratılmasında aracıdır. Mekan, tüm zaman dilimleri içerisinde insan yaşamının sürdürüldüğü önemli bir mecradır. Dış dünya ve nesneler insanın iç dünyasından ayrı değildir. Dış dünya ile birlikte var olan, onunla anlam kazanan insan, mekan ve onu oluşturan nesneler dünyasıyla uyum sağladığında iç dünyasını da düzenlemektedir. İnsan, dış dünyayla ve nesnelerle iç dünyası arasında uyum sağlayamadığında huzurlu ve uyumlu bir yaşama alanı da kuramamaktadır.

Yapılan bazı psikolojik içerikli araştırmalar çerçevesinde sosyal medya oyunlarının oyun kullanıcılarının ev içinde aile bireyleri ile iletişimlerinde gerilemeye, sosyal çevrelerinin daralmasına, depresyon ve yalnızlık duygularının derinleşmesine neden olduğu tespit edilmiştir (Castells, 2005: 477). Günümüz toplumları her gün biraz daha bireyselleşmekte, değişmekte ve sanal dünyaya bağlı olmaktadır. Her şeyin sürekli değiştiği bir dünyada herhangi bir belirliliğin, kesinliğin bireye kadar ulaşması zor görünmektedir (Berger, 2001: 202,203).

Sosyal medya oyunlarının gerçek yaşamsal mekanlara yakın ortamlar sunması ve iletişımde sınır tanımaması çoğu sosyal aktivitelerin sosyal ağlarda yapılmak istemesine sebep olmaktadır. Gerçek yaşamsal mekanlarda gerçekleştirilen sosyal aktiviteler hem maliyet hem de fiziksel eylem gerektirmektedir. Sosyal medya oyunları eylemin yanında hareketi de sağladığı için arttırılmış gerçekliği sağlamaktadır. Yeni sosyal medya oyunlarının üç boyutlu olması bu oyunların daha fazla sanal aktivitelere hizmet etmeye başlamıştır. Söz konusu bu oyunlardaki sanal mekanlardaki sosyal aktivitelere örnek olarak; diskoda dans edebilme, çiftlikte hayvan yetiştirebilme, serada bitkileri ekip büyütebilme, kumsalda yüzebilme, çeşitli sportif aktivitelerde bulunabilme, bireylerin kendilerinin dekore edebileceği çok sayıda odalarının bulunabilmesi, alışveriş ederek oyundaki evler ve oluşturdukları 
karakterler için ürünler satın alabilmeleri, Youtube'dan istedikleri videoları ağdaki tüm kullanıcılara izletebilmeleri, farklı coğrafyalardaki insanlarla sohbet edebilmeleri verilebilir. $\mathrm{Bu}$ oyunlarla sosyal aktiviteler artık gerçek yaşamsal mekanlardan sanal mekanlara taşınmıştır.

Sanal mekanların sağladığı imkanlar sosyalleşmede gerçekliğe bakışı dönüştürmüş ve gerçeğin sahtesinin gerçekmiş gibi algılanmasına neden olmuştur (Baudrillard, 1991: 22). Bu durum sanal ve kurgusal olan mekanlara bağlilığın giderek artmasına neden olmaktadır. Kurgu dünyasının zamanla daha fazla egemen olması sanal mekanlarda yapilabilen aktivitelere yakın bir gelecekte sinır tanımayacaktır. Son zamanlarda sosyal medya oyunlarında sanal evliliklerin dahi yapılabilmesi mekansal dönüşümün sanallaşmayı ne kadar uç noktalara taşıyabildiğinin bir göstergesidir. Kurgusal mekanların gerçek yaşam mekanlarına tercih edilmesi ve sanal dünyanın gerçek yaşamın önüne geçmeye başlaması zaman içerisinde gerçek yaşamsal sosyal aktivitelerin büyük ölçüde tükeneceğinin bir işaretidir.

Sosyal medya oyunları bireylerin kişisel gizliliklerini ve mahremiyetlerini izleyicilerden oluşmuş gözetmenlerin önüne açık bir şekilde sermektedir. Gözler önüne serilen yaşamların gözetlenmesi gözetmen iktidarların etkinliğini arttırmaktadır. Modern toplumda iktidar biçiminin anlatması bakımından en etkin model Jeremey Bentham'ın tasarladığı kapatma modeli panoptikon'dur. Bu model temelde bir hapishanenin ortasına kurulu bir kuleden tüm mahkumların gözetilmesine dayalı bir sistemdir. Panoptikon modeli etrafında gerçekleştirilen gözetim iktidar karşısında toplumun bir ütopyasıdır. Bu sistem günümüzde özellikle sosyal medya ve sosyal medya oyunları ile gerçekleşmiş bir ütopyadır. Panoptik iktidar gözetlemenin merkezileşmesidir. Gözetmenler gözetledikleri bireyler üzerinde bilgi sahibi olarak bir iktidar gücü elde etmektedirler. $\mathrm{Bu}$ süreçle artık bireylerin Facebook'da paylaştıkları kişisel bilgilerinden, enformasyon dağılımının kamuoyu ve gündem oluşturmasına kadar tüm iletişim öğeleri önem kazanmaktadır. (Foucault, 2006: 22). Sanal yaşamdaki tüm gözetim unsurları bireyleri gerçek yaşamda da gözetleyenin kurallarına uygun davranışlar göstermeye itmektedir (Dedeoğlu; 2006: 82). Sosyal medya ve sosyal medya oyunları günümüzde 
gözetlenmenin ve gözetlemenin en açık yaşandığı mekanlardan biri konumundadır. Bu mekanlarda tüm ülkelerdeki bireyler çevrimiçi ve eşzamanlı iletişim kurmanın ve de paylaşılan enformasyona anında ulaşabilmenin verdiği özgürlük içerisinde kolaylıkla birbirlerini gözetleyebilmekte ve birbirlerinin iktidarı olabilmektedirler. Panoptik sistemin sosyal medya oyunlarındaki merkezi işlevselliği zaman içerisinde gözetlenmenin sınır tanımazlığını hızla arttıracak ve bireylerin mahremiyetlerinin kendi gönüllü rızalarıyla yok olmasına sebep olacaktır. Bu durum sanallaşmanın gerçekliğin ötesine geçmesine ve panoptikonun yargılanmayarak kabul edilmesine yol açmaktadır. Gelişen yeni bilgi teknolojileri modern insanın yaşamındaki özel alaların her geçen gün daralmasına neden olmaktadır. Yeni teknolojiler, panoptikon sisteminin bir aracı haline gelerek, kamusal ve özel alan tartışmalarını arttırmış ve bu iki alan arasındaki sınırları gevşeterek hızla yok olma sürecine sokmuştur.

\section{5. Çalışmanın Amacı ve Yöntemi}

$\mathrm{Bu}$ çalışmada sosyal medya oyunlarından "Smeet" oyunu örnek olarak incelenmiştir. Çalışmada smeet sosyal medya oyunun işlevsel özelliklerinin neler olduğunun, bu oyunun işlevsel özelliklerinin aşınarak nasıl bağımlılığa dönüştüğünün, oyunun iletişimde gerçek temas ve mesafe üzerindeki etkilerinin neler olduğunun ve söz konusu oyunun zamansal değeri ve gerçek mekansal düzeni nasıl sanallığa taşıdığının araştırılması amaçlanmıştır.

Örnek olarak smeet oyunun seçilme nedeni; bu oyunun diğer $3 \mathrm{~d}$ sosyal medya oyunlarının bir çoğunun içerdiği farklı oyunları bir araya toplayacak kadar çok sayıda oyunları ve yarışmaları içerisinde barındırması, Mynet üzerinden oynanan bu oyunun 6.5 milyonu aşan üye sayısının olması nedeniyle geniş bir kitleye hitap etmesi ve sanal yaşamı gerçekliğe taşıyan öncü oyunlardan biri olarak görülmesidir.

Çalışmada smeet oyunu monografik örnekleme tekniği altında örnek olay monografisi ile analiz edilmiştir. Monografik örneklemede eldeki bilgilere dayanılarak tasvir edilmek istenen ana kitlenin herhangi bir alt grubu, ana kitleyi temsil edeceği varsayılarak, örneklem olarak seçilir. Analiz edilen parçalar arasında karşılaştırmalar yapılır; birimlerin tek tek tasviri ile örneklemin tasvirine ve örneklemin tasvirinden de ana kitleye ait genellemelerde bulunulur; örneklem 
vasıtasıyla ana kitle tasvir edilir. Çalışmada örnek olay olarak smeet sosyal oyunu ele alınmıştır. Monografik örnekleme tek birimli örneklemdir. Smeet oyunu tek örnek olarak seçilerek oyunla ilgili saptamalarda bulunulmuştur. Araştırmada öncelikle smeet oyunun işlevsel özellikleri tespit edilmeye çalışılmıştır. Bu amaçla bu oyunun içerdiği tüm oyunlar, oyun odaları, kullanıcı profilleri, kullanıcıların karşılıklı iletişimleri 1 yıl boyunca günde dört saat oyun içerisinde çevrimiçi olarak gözlenmiştir. Gözlemlemede 500 kullanıcı profili, 1000'in üzerinde kullanıcılar arasındaki iletişim diyalogları ve 55 farklı oyun odası incelenmiştir. Smeet sosyal medya oyunun genel özellikleri, kullanıcılar üzerindeki etkileri, oyunun zamansal ve mekansal özellikleri, iletişimde temassal ve mesafesel nitelikleri, oyunun sanal sosyal aktivitelerinin gerçek yaşamdaki sosyal aktivitelere olan etkilerinin neler olduğunun araştırılması için 150 oyun kullanıcı ve 12 site yöneticisi ile 1 yıl içerisinde çevrimiçi olarak derinlemesine görüşme yapılmıştır. Derinlemesine görüşme; araştırmacının hazırlanan sorulara bağlı kalarak ya da bağımsız olarak yanıtlayanın belirli sorulara yanıt vermesini sağlaması ve daha sonra bu yanıtların arkasındaki nedenleri öğrenmeye çalışması sürecini içeren bir tekniktir. 150 oyun kullanıcısı ile çevrimiçi iletişimde bulunularak oyun hakkındaki genel görüşleri, oyuna ne kadar zaman ayırdıkları, oyun içerisindeki sosyal aktivitelerin günlük yaşamlarında nasıl bir yer tuttuğu, sanal mekanların kullanıcılar için nasıl algılandığı, sanal ortamda zamansal faktörlerin onlar için önemi, sanal ortamdaki iletişimlerinde temassal nitelikleri ve birbirlerine olan yakınlığı nasıl buldukları üzerine derinlemesine görüşmeler yapılmıştır. 500'ün üzerinde kullanıcı profili incelenerek oyun kullanıcılarının demografik özellikleri, tüketim alışkanlıkları ve arkadaş listeleri incelenmiştir. 1000'in üzerinde kullanıcılar arasındaki diyaloglar incelenerek oyun kullanıcılarının iletişimlerinde konuşma biçimleri ve konuştukları konular değerlendirilerek onların sanal ortamdaki yaşam tarzları, sosyal aktiviteleri, birbirleriyle nasıl bir temasta bulundukları değerlendirilmiştir. 55 farklı oyun odası incelenerek oyun kullanıcılarının sanal mekanlarda ne tür sosyal aktivitelerde bulundukları, odaların tasarımlarının gerçek yaşamda arzulanan yaşam biçimlerini nasıl ifade ettiği araştırılmıştır. 
Oyun yöneticileriyle de yüzyüze görüşme imkanı olmadığı için çevrimiçi iletişim ile derinlemesine görüşme yapılarak smeet oyunun özellikleri hakkında genel bilgiler edinilmiştir. Bu amaçla monografik örneklemede smeet oyunun yöneticileri olarak 2 admin, 2 amir, 4 organizatör ve 4 op ile iletişime geçilmiştir. Oyun yöneticilerinden alınan bilgiler, verilmiş olan referanslara gönderme yapmıştır. Smeet oyunu adminler, amirler, oganizatörler ve oplar tarafindan düzenlenmekte ve denetlenmektedir. Türkiye'de smeet oyunu için hiyerarşik sınıflamaya göre 2 tane admin, 2 tane amir, 4 tane organizatör ve üst yönetimce istenildiği zaman istenildiği kadar seçilebilen ve görevleri doğrultusunda yetiştirilen smeet oyun kullanıcılarından oluşan oplar bulunmaktadır. Adminler; en üst düzeyde oyunu yöneten ve denetleyen yöneticilerdir. Amirler; sohbet ortamında bulunan operatörleri, organizatörleri ve rozet kullanıcılarını olağanüstü durumlarda kendilerine yönlendirip sorunu kısa zamanda çözüme ulaştırmaktadır. Organizatörler; smeet oyunu içerisindeki çeşitli sosyal aktiviteleri (düğün, eğlence, parti vs.) düzenlemektedirler. Oplar; oyun kullanıcılarının içinden seçilmektedir. Oyun kullanıcıları içersinde op olmak isteyen kişiler site yönetimi tarafından duyurulan op alımları zamanlarında yönetime başvurmaktadırlar. Yöneticiler op adaylarının ne kadar zamandır bu oyunun üyesi olduklarına ve oyun hakkında ne kadar bilgili olduklarını incelemektedirler. $\mathrm{Bu}$ amaçla adayların kullanıcı profillerine ve oyun puanlarına bakılmaktadır. Adayların oyun hakkındaki bilgilerinin değerlendirilmesi için adaylar çevrimiçi olarak yapılan ve test şeklinde olan bir sınava tabi tutulurlar. Tüm bu değerlendirmeler sonucunda başarılı olan adaylar opluğa kabul edilirler. Kabul edilen oplara bir ay boyunca site üzerinden çevrimiçi olarak eğitim verilir. Opların genel görevi oyun üyelerinin aktivitelerini denetlemek ve gerektiğinde onları uyararak ya da oyundan uzaklaştırarak müdahale etmektir. Oplar oyunda gönüllü olarak çalıştıkları için onlara herhangi bir maddi bedel ödenmemektedir. Opların maddi beklenti içinde olmadan zamanlarının büyük bir bölümünü bu görev için harcamaları onların smeet sosyal medya oyununa bağlılıklarının oldukça güçlü olduğunu göstermektedir.

\section{6. Çalışmanın Bulguları}

Smeet oyunu eğlence odaklı üç boyutlu bir sosyal medya oyunudur. İngilizcede See-Meet-Talk (gör-tanış-konuş) kelimelerinden türetilmiş olan smeet, 
kurulduğu ilk günden beri kitlelere sağladığı interaktif ve eğlenceli imkanlardan dolayı birçok ülkede sevilerek oynanan bir oyundur. Bir Alman firmasının ürünü olan Smeet sosyal medya oyunu Türkiye'de Mynet sitesine bağlıdır. Üç boyutlu sosyal medya oyunu olarak adlandırabilen smeet oyununda gerçek yaşamdan referans alınan pek çok aktivite bulunmaktadır. Smeet, bireylerin sosyal ağdaki arkadaşlarıyla sohbet edebileceği, yeni arkadaşlıklar edinebileceği, çeşitli oyunlar oynayabileceği, sesli ya da yazılı iletişim kurabileceği bir ortamdır. Bu oyunda oyuncular kendi sanal yaşam alanlarında odalarını ya da avatarlarını hayal güçlerine göre farklı şekillerde dizayn edebilir ve herkesin bunu görmesini sağlayabilirler. Smeet oyunu oyun kullanıcılarına yerine getirmesi gereken bazı eğlenceli görevler de vermektedir. Örneğin, su verilerek büyütülebilecek interaktif bitkilerin ya da sevgi ve ilgi gösterilerek büyütülebilecek çeşitli hayvanların sahibi olunabilinmektedir. Bütün bu görevler yapılarak şöhret puanları kazanılmakta ve biriken şöhret puanlarla bir üst seviyeye çıkılmaktadır. Smeette ne kadar aktif olunursa o kadar hızlı bir şekilde üst seviyelere ulaşılmaktadır. Her seviye beraberinde ilginç ve güzel hediyeler getirmektedir. Kimi zaman müzik odası ya da salon için çok gösterişli bir piyano, kimi zaman da avatara farklı görünüşler verilebilecek giysiler ve kişisel eşyalar hediye verilebilmektedir. Bu özelliklerin yanında genel kültürü ve kelime hazinesini geliştirecek ya da sayısal nitelikte olan yarışmalar da bulunmaktadır. $\mathrm{Bu}$ yarışmalarda diğer smeet kullanıcılarıyla aynı anda yarışılmakta ve bu sayede yeni arkadaşlıklar edinilmektedir. Bu oyunda eşya, hayvan, bitki ya da kıyafet sahibi olabilmek ve puan yükseltebilmek için smeet coins almak gerekmektedir. Coinsler kredi kartı ya da cep telefonundan kontör karşılığı alınarak dijital tüketim sağlanmaktadır (www.mynet.com/blog).

Sosyal medya bireylerin yaşam tarzlarını, eğlenme ve çalışma biçimlerini değiştirmektedir (Qualman, 2009). Smeet sosyal medya oyunu işlevsel özellikleri bakımından oyun kullanıcılarına eğlenceli vakit geçirme ve boş zamanları değerlendirme imkanı sağlamaktadır. Kitle iletişim araçlarının işlevlerinden biri olan eğlendirme işlevi bu oyunda sosyal aktivitelere katılma yoluyla daha etkin olmaktadır. Kullanıcıların sanal yaşam aktivitelerini gerçek yaşam aktivitelerine göre daha fazla tercih etmelerinde oyunun sağladığı gerçekliğin sahtesinin birebir 
yansıtılması etkili olmaktadır. Oyun yöneticileri, smeet oyunun kullanıcıları daha fazla etkilemesi için gerçek yaşamda yaşanabilecek aynı zamanda hayal dünyasına da hitap edebilecek pek çok aktiviteye yer ayırmaya çalışmaktadırlar. İsteyen kullanıcılar gerçek yaşamda yaşanabilen ancak sanal dünyaya aktarılmış sosyal aktivitelerinde bulunurken, isteyen kullanıcılar ise hayal dünyalarına hitap edebilecek aktiviteleri bu oyunda birebir yaşama imkanı bulmaktadırlar. Smeet sosyal medya oyunu sanal dünyanın bir ürünüdür. Gerçek yaşamdan referans alınarak oluşturulan tüm öğeler bu evrenin yegane unsurlarıdır. Temelde bakıldığında bu oyunun popüler ve ilgi çekici olmasında oyunun çekiciliğini arttıran bazı unsurlar yatmaktadır. Smeet oyunun ilgi görmesindeki önemli sebeplerden birisi oyun kullanıcılarına gerçek yaşamdan kesitler sunmasıdır. $\mathrm{Bu}$ oyunda kullanıcıların kendilerine ait evleri bulunmaktadır. Bu evlerde dekorasyonlarını kendilerinin tasarladıkları ve kendilerine ait olan diledikleri kadar oda sahibi olabilme özgürlükleri bulunmaktadır. Sanal mekanlaşmanın bu oyunda ön planda olması gerçeklik algılayışlarını etkilemektedir. Sanal evler gündelik yaşamın bir parçası haline gelmeye başlamıştır. Bu evlerin içerisinde yapılabilen aktiviteler gündelik yaşamın sahtesinin gerçekmiş gibi kabul edildiği bir konumundadır. Oyun odalarının ve kullanıcılarının günlük aktiviteleri gözlemlendiğinde; smeet oyununda gerçek yaşamsal aktivitelerin sanal yaşama uyarlaması olarak; kullanıcıların kendilerine ait evlerinin olması, evlerinin odalarındaki eşyalarını diledikleri gibi döşeyebilmeleri, sportif aktivitelerde bulunabilmeleri, ev içinde parti verebilmeleri, dijital platformda alışveriş yapabilmeleri, sinemaya gidebilmeleri, ormanda ve kumsalda yürüyüş yapabilmeleri, Youtube'dan seçilen videoları diğer kullanıcılarla paylaşabilmeleri, misafirlerini evlerinde ağırlayabilmeleri ve hatta oyun kullanıcıları arasında sanal evliliklerin dahi yapılabilmesi görülmüştür. Bu gözlemlemelere göre smeet oyununda hayallere hitap eden aktivitelerinin sanal dünyaya aktarımında ise, beyaz saray odası, bulut odası, ay odası, hazine odası gibi odaların bulunduğu görülmüştür. Bunların dışında şatoda yaşam, uzayda yaşam, denizaltı yaşamı, uçakta parti verebilme ve evlerin önünden roket firlatabilme gibi pek çok farklı yaşam biçimlerinin de oyun kullanıcılarına sunulduğu gözlemlenmiştir. Görünürde smeet sosyal medya oyununun işlevsel olarak nitelendirilebilen bu özellikleri aslına bakıldığında kullanıcıların giderek daha fazla bağlandıkları birer gerçek yaşam aktivitesi haline gelmiştir. 
Gerçekliğin sanal bir gerçekliğe dönüşümü imajlar yoluyla olmaktadır. Oyun kullanıcıları kendilerine sunulan sanal ortamlarda birbirinden farklı mekanlarda gerçeğin bir taklidi olarak bir simülasyon evreni içerisindedirler. Bireyler bu simülasyon evreninden kendilerini kurtaramamaktadır. Ekran, gerçekliğe katkıda bulunmak yerine gerçekliğin yerini almaktadır. Ekrandaki imajlar, görüntülenmiş gerçekliğin yokluğunu ve uzaklığını onaylamaktadır (Robins, 1999: 103). Kurgusallığın sınır tanımadığı sanal mekanlarda gerçek yaşam algılayışı da boyut değiştirmektedir. Oyun kullanıcıları ile yapılan görüşmelere göre, smeet oyunu kullanıcıları kendi evlerinde kendi yaşam tarzlarında vakit geçirmek yerine sanal üç boyutlu sanal bir ev ortamlarında vakit geçirmeyi daha eğlenceli bulmaya başlamışlardır. $\mathrm{Bu}$ mekanlarda lüksün ve ihtişamın tüm olanaklarının kullanılabilmesi hayallerin sanal yaşamla karşılanmasını gündeme getirmektedir. Hayallere bir köprü kuran bu oyunda beyaz saray odas1, hazine odası, buz odası gibi odalarda da vakit geçirme imkanın bulunması kurgusallığı en uç noktalara kadar taşımaktadır. Smeet oyunu güç ve prestijin sanal olarak sahip olunabileceği bir mekan konumundadır. Bu oyunda sahip olunan tüm sanal maddi değerler (eşyalar, kıyafetler, elmas ağaçları, hazineler vs.) ve yüksek puanlar sanal bir zenginliği oluşturmaktadır. Bu zenginlik aynı zamanda oyunda daha kolay ve daha fazla arkadaş edinmeyi de sağlamaktadır. Oyuncuların sanal olarak zengin sayılabilmeleri yaptıkları tüketim miktarıyla orantılı olmaktadır. Smeet sosyal medya oyunu günümüzde sadece oyun oynamayı temsil etmeyip bireylere farklı yaşam tarzları da sunmaktadır. Kullanıcılara sunulan yaşam tarzı zenginliğin ve ihtişamın olduğu, birçok sosyal aktiviteye dahil olunduğu, yoğun bir arkadaş çevresinin bulunduğu ve özgürce yaşanan bir hayat biçimidir. Çoğu kişi tarafından gerçekleştirilmek istenen bu yaşam tarzı sanal dünyada gerçekmiş gibi yaşanmaktadır. İletişim kurulan oyun yöneticileri ve kullanıcılarına göre bu özgürlüğü sunmaktan oyun yöneticileri, yaşamaktan ise oyun kullanıcıları mutlu olmaktadır.

Smeet sosyal medya oyununda puan seviyesi olarak 0-200 arası seviye aralığ1 bulunmaktadır. Oyun içerisindeki gözlemlemelere ve oyun kullanıcıları ile olan görüşmelere göre, bu oyunda seviyeyi yükseltebilmek için günlük görevlerin düzenli olarak yapılması ve coins alımı ile site içinden alışveriş yapılması gerekmektedir. 
Günlük görevlerin yanında oyun kullanıcıları hayallerine hitap eden her türlü ürünü de sanal ortamda satın alarak aynı ortamda tüketmektedirler. Günümüz tüketicileri ürünü öykülemeye ve bir üretici gibi düşünmeye odaklanmakta; ürüne değil, yaşattığ1 hayallerine önem vermektedirler (Sennett, 2009: 102-105). Smeet sosyal medya oyununda alışveriş yapmak tüketiciler için hayal dünyasına çıkmayı kolaylaştıran bir merdiven konumundadır. Tüketim kültürünü içselleştiren yeni tüketiciden, kendisine sunulan tüketim kalıplarına göre farklı kişilik tiplerine bürünmesi istenmektedir (Baudrillard, 2003: 83).

Tüketimin alanı tam olarak iste bu ikinci alandır. Bu alanda her tür nesne, anlam verici öğe olarak çamaşır makinesinin yerine geçebilir. Simgelerin mantığında olduğu gibi, göstergelerin mantığında da nesneler artık hiç bir işleve ya da tanımlı bir ihtiyaca bağlı değildir. Bu tam olarak nesnelerin başka bir şeye cevap vermesindendir. İster toplumsalın mantığı ister arzunun mantığı olsun, bu başka şeye nesneler hareketli ve bilinçdışı anlamlandırma alanı olarak hizmet eder (Baudrillard, 2004: 89).

Oyun kullanıcılarının profilleri ve alışveriş yaptıkları ürünler incelendiğinde kullanıcıların belirttikleri kişisel özellikleri ile alışveriş yaptıkları ürünler arasında çatışmalar görülmüştür. Örneğin kendisini ev hanımı ve sakin bir yaşam tarzını benimseyen bir kişi olarak nitelendiren kullanıcının oyunda kovboy ve parti elbiselerinin olduğu, şatoda yaşam sürdüğü ve de oyun evinde s1k sı parti verdiği görülmüştür. Aynı şekilde profilinde kendisini çılgın bir yaşamı benimseyen biri olarak nitelendiren bir kişinin oyundaki sosyal aktivitelerinde balık tutmak, satranç oynamak, sinemaya gitmek gibi aktivitelerde bulunduğu görülmüştür. Bu durum kullanıcıların profil özelliklerinin ve sosyal aktivitelerinin sık sık değişiminin onları sürekli hayallerindeki farklı kimliklere büründürdüğünü göstermektedir.

Smeet sosyal medya oyununda yapılan sanal alışverişler sadece puan kazanmaya yönelik değil aynı zamanda gerçek yaşamı sanallık içerisinde çok daha sınırsız yaşamaya hizmet etmektedir. Günlük yaşamın referans alındığı günlük görevler incelendiğinde gerçek yaşam günlük görevlerinin bu oyunda benzer özelliklerde yaşandığı fark edilmektedir. Yapılan bu günlük görevler; yemek yapmak, bulaşık yıkamak, süt sağmak, elma toplamak, balık tutmak, hayvan beslemek ve de odaları temizlemek ve düzenlemektir. Bireylerin kendilerine ve topluma ne kadar yakın ya da ne kadar uzak olduğu gerçeklik kavramını 
sorgulamaya itecek kadar gündelik yaşam deneyimlerinde saklıdır. Deneyimlerin hakikiliği, kimliklerin sabitliği bu karmaşık, dahası ideolojilere bulanık arenada "katı olan her şey" gibi buharlaşmaktadır (Berman,1999). Tüm sosyal ve gündelik yaşam aktivitelerinin bu sosyal medya oyununa sığdırılması oyun içerisinde harcanan zamanı da arttırmaktadır. Kullanıcılarla kurulan iletişimler ve de kullanıcıların seviye puanları, yaptıkları görevler ve rozetleri incelendiğinde 150-200 seviye arası puanı olanların oyunu günde 5-15 saat arası ziyaret etikleri, daha fazla alışveriş ettikleri, günlük görevlerini her gün düzenli olarak yaptıkları ve bu alışverişleri yapmaları ve görevleri yerine getirmeleri karşılığı oyun yöneticileri tarafından ya da otomatik olarak verilen puanların, coinslerin, odaların, eşyaların ve rozetlerin ödül olarak verildiği görülmüştür. Smeet oyununda sosyal ağ içerisinde yapılan yarışmaların kazanıldığı durumlarda verdiği ödüllerle kullanıcıları daha fazla kendine bağlamaktadır. Yarışmaların verdiği kazanma hırsı bireyleri sürekli daha fazla oynayarak daha çok ödül kazanma yoluna itmektedir.

$\mathrm{Bu}$ oyunda, tüketiciler yaptıkları alışverişler ile kurdukları sanal dünyanın öylesine içindedirler ki bu iç içe olma durumu onları giderek oyuna bağlılıktan bağımlı olma durumuna getirmektedir. Oyun içerisinde harcanan zamanın 15 saat ve üzerine kadar ulaşmaya başlaması özellikle yüksek seviyeye sahip olan kullanıcıların oyuna bağımlı hale gelmeye başladıklarını göstermektedir. Özellikle yalnızlık içerisinde olan ve içine kapanık olan bireyler günlük yaşamdaki sosyalizasyonun kendilerine verdiği sıkıntıyı yok edebilmek için sosyal medya oyunlarına yönelmektedirler (Dolgun, 2005: 135). Sosyal medya oyunlarında ortalama bir oyuncunun geçirdiği zaman haftalık 5.7 oturum civarındadır. $\mathrm{Bu}$ veriye göre, oyuncunun oyun dünyasına "bağlanmasının" ya da diğer bir deyişle "adanmışlığının" gerçek yaşama ve toplumsal ilişkilere etkisinin boyutları daha fazla kavranabilir hale gelecektir. Gerçek hayatta, kendini ifade edemeyen içe kapanık bireyler, sosyal medyada kendilerini çevresine gösterme gayretine girmekte ve sosyalleşmeye yönelik arayışlarını sosyal medyada kurdukları iletişim ile bastırmaya çalışmaktadırlar (Binark, 2005: 3). Bu durum ise onları gerçek hayattan daha da soyutlayıp, sosyal ağlara bağımlı bir kişilik olmalarına sebep olmaktadır. Sosyal medya oyunlarının kullanımı dikkate alındığında erkeklerin \% 51, kadınların ise \% 
49 oranında istatistiklerde yer aldığı görülmektedir (Chip, 2011: 18). Bu durum sosyal medya oyunlarının kullanıcıları cinsiyet farkı gözetmeksizin kendilerine bağladığını göstermektedir.

Teknolojik girişimlerin yaratıcıları olan güçler, kültürlerini dünyaya pazarlayarak kendi ideolojilerini diğer ülkelere yaymaktadırlar (Büyükbaykal, 2008). Smeet sosyal medya oyunu yaptığ 1 farklı yarışmalarla yaratılmak istenen farklı kültürlerin sorgulanmasını da bir yana itmektedir. $\mathrm{Bu}$ oyunda oyun organizatörlerince düzenlenen genel kültür, kelime oyunu ve sayısal oyunlar gibi bilinen yarışmalar olduğu gibi çift uyumu gibi sıra dışı yarışmalar da bulunmaktadır. Organizatörler bu tip farklı yarışmaları kullanıcıların dikkatlerini çekmek, smeet oyununa bağlılıklarını arttırabilmek ve kültürler arası bir etkileşim yaratabilmek amacıyla hazırlamaktadırlar. Çift uyumu yarışmasında sosyal ağdaki bir yarışmacıyla yarışılmaktadır. Kişisel hobileri ya da kişisel özellikleri tanımlaya yardımcı olacak şekilde her iki tarafa da aynı sorular sorulmakta ve iki taraf da birbirlerinin cevaplarını görmeden kendilerini tanımlayan şıkları işaretlemektedir. Aynı şıkların işaretlenme sayısı ne kadar fazla ise o çiftlerde o derece yüksek uyum çıkmaktadır. Çift uyumu mükemmel ise bu çiftler smeet evliliğine davet edilmekte ve smeet sitede verilecek dügün ile evlendirilmektedirler. Oyunda evlenen çiftler kendi istekleri ile ayrılıncaya kadar evli kalmaktadır. Yapılan sanal evlilikler aylarca sürebilmektedir. Sanal kurgusal evren artık evlilik kültürüne kadar uzanmıştır. Bu durum gerçek yaşamda birçok maddi ve manevi külfetle yapılabilen evlilikleri sanal ortamda çok basite indirgemiştir. Sanal evliliklerin yapılabilir hale gelmesi evlilik kültürüne bakışı dönüştürmektedir. Görücü usulü ile yapılan evlilikler artık sosyal medya oyunlarına taşınmıştır. Oyunda birbirlerini görmeden tanışan oyun kullanıcıları birbirlerini çift uyumu gibi yarışmalar ile tanıyarak sanal ortamda evlenmektedirler. Televizyonlarda yapılan evlendirme programlarına benzeyen bu durum ileride sanal evliliklerin daha fazla yaygınlaşacağını göstermektedir. Bu durum smeet sosyal medya oyununu, işlevsel özelliklerinden çıkarak kullanıcıların bağlılıklarını kuvvetlendirecek bir etki mekanizmasına sahip olmasını kolaylaştırmaktadır.

Son zamanlarda sosyal medya olarak tanımlanan internet tabanl uygulamalarda kullanıcıların iletişim kurdukları kişiler arasında daha çok artan bir 
etkileşim sağlamaktadır. Bu etkileşimde, fotoğraf, video, metin ve sosyal medyaya ilişkin farklı oyunlarda yer almak etkili olmaktadır (Komito ve Bates, 2009: 233). Sosyal medya çevrimiçi olarak ağ kurma teknolojisi ile bir bakıma doğal sosyal davranışları yakından yansıtacak şekilde insanlarla iletişim kurmayı mümkün kılmaktadır (Neumann vd., 2005: 479-485). Aslına bakıldığında sosyal medyada ve sosyal medya oyunlarında iletişim gruplarının büyümesi, grup içindeki bireylerle etkili bir iletişime girilmesini imkansız kılmaktadır. İki oyun kullanıcısı arasındaki iletişime aynı anda ikiden fazla kişinin girebilmesi iletişimin bir parazit (gürültü) haline gelmesine sebep olmaktadır (Shirky, 2008: 30). Sosyal aktivitelerin yüzyüze temassal olmasından giderek uzaklaşıldığı sanal oyun mekanlarında her şey sanal bir yapaylığa indirgenmiştir. Bu kurgusal sahtelik içerisinde iletişim de ekranın ardından temassallıktan uzak olarak sürdürülmektedir. Yüzyüze temassal çift yönlü iletişimin yerine geçmeye başlayan sanal iletişim tüm imkanlarıyla bireyleri etkisi altına almaktadır (Barabas1, 2010).

Smeet sosyal medya oyununda oyun kullanıcıları arasındaki diyaloglar gözlemlendiğinde, iletişim kurmada bu oyunun bir aracı haline gelmesi smeet oyununa yüklenen anlamı "iletişimsel buluşma mekanı" haline getirmiştir. Oyun kullanıcılarının birbirinden farklı özellikteki sanal mekanlarda buluşarak hem iletişim kurmaları hem de birlikte sanal sosyal yaşamda aktivitelerde bulunmaları iletişimde gerçekliğin giderek daha fazla kaybolmasına neden olacaktır. Temassal iletişimin giderek azalması insanlar arasındaki mesafe olgusunu da değiştirmektedir. Farklı coğrafyalardaki insanların sanal sosyal ortamlarda bir araya gelebilmeleri iletişimde mesafeleri azaltmıştır. Ancak bu şekilde kurulan bir iletişimde gerçek bir temas sağlanamadığı için insanlar arasında temassal mesafe artmaktadır. Smeet oyunun içerisindeki tüm mekanlarda sanal iletişim kurulması iletişimde kalite anlayışını düşürmektedir. İletişimde kalite anlayışından, kurulan çift yönlü iletişimde iletişimin dilbilgisel olarak düzgün olması anlaş1labilir. Smeet oyunu gibi diğer sosyal oyun ağlarında da bireyler sınırsız sunulan konuşma olanaklarını değerlendirmek için anlamlı anlamsız pek çok cümlecik sarfetmektedir. Ancak iletişimin bu denli geniş sınırlarda yapılması iletişimle sağlanan enformasyonun çok 
fazla sayıda ancak giderek anlamsız bir hale gelmesine neden olmaktadır. Bu durum da iletişim kalitesinin giderek daha fazla azalmasına neden olmaktadır.

Sosyal medya oyunlarında bir başka önemli sorun ise "gözetim" olgusudur. İnternet teknolojisinin gelişimine paralel olarak gözetim kavramı, son dönem literatüründe önemli bir yer edinmiştir. Smeet sosyal medya oyununda da kullanıcı profilleri, kullanıcılar arasındaki diyaloglar, tüketim alışkanlıkları, puan seviyeleri, arkadaşlık listeleri, kullanıcıların kişisel bilgileri, kullanıcı odaları ve yapılan her türlü sosyal aktiviteler diğer kullanıcılarca gözetlenebilmektedir. Sosyal medya oyunlarının bireylere özgürlük ve paylaşılmış birliktelik sunmasının yanı sıra küresel gözetime ve bireysel yabancılaşmaya da yol açtığı sosyal bilimciler tarafindan tartışılmaktadır. Tartışmanın merkezinde bilişim teknolojilerinin geçmişin teknik biliminden farklı olarak bilgiyi indeksleyebilmesi özelliği bulunmaktadır. Kişinin özel bilgilerini küresel, interaktif dünyaya sunması ve bu bilgilerin kamusal alana sızması günümüzde aşırı boyutlara ulaşmış durumdadır. Bilgi toplama sistemleri, Twitter, Facebook gibi sosyal paylaşım sitelerini, blogları ve diğer web içeriklerini analiz ederek kişisel bilgilerin raporlanması imkanını sunmaktadır. Dolayısıyla, kişilere ait özel bilgiler, fotoğraf ve içerik paylaşımları oyun kullanıcılarının izni olmaksızın, görünmeksizin ya da bilinmeksizin başkaları tarafından izlenebilir hale gelmiştir (Özarslan ve Çoban 2008: 139). Gözetim ve özel yaşamın gizliliği kavramlarını açıklayabilmek için Michel Foucault ve onun "Panoptikon" düşüncesini kullanabilir. Varolan sosyal düzene uygunlukla ilişkili olan ve sosyal denetimin bir aracı haline gelen gözetim, eski çağlardan bu yana süregelen bir eylemdir. İçinde bulunulan durumun ve dönemin şartlarına uygun olarak şekil alan gözetim kavramı, açıktır ki; teknolojinin evrilmesi, istenilen anda bilgiye ulaşabilme kolaylığının yanı sıra yasal ya da yasal olmayarak kurumları ya da kişileri gözetime teşvik etmektedir. İktidarın yeniden üretilmesi, verimlilik ve üretkenlik gibi hedefleri olan gözetim, Foucault'a göre, sosyal ilişkilerin alanını genişletmektedir. Gözetim, bireyleri her yerde bulunan iktidarların kontrol altında tutulan bir gözetim parçası haline getirmektedir. Gözetlemek kelimesinden türetilmiş olan gözetim düşüncesinin temelinde haberdar olmak, bilmek kaygısı ve görme arzusu yatmaktadır. Foucault, iktidarın bilgiye, bilginin de iktidara sürekli eklemlendiğini ve iktidar işleyişinin bilgi 
nesneleri yarattığııı, bunları ortaya çıkardığını, enformasyon biriktirdiğini ve kullandığını ileri sürmektedir (Foucault, 2006, 292-298). Gözetim görmeye dayalıdır ve kesinlemeyi, tasarımlamayı, düşünmeyi, yorumlamayı, bilgiyi, egemenliğini, gücü ve iktidarı içerisinde barındırmaktadır (Dolgun, 2008: 30). Modern toplumda bilgiye sahip olmak iktidar olmaktır (Bauman, 2003: 62). Smeet oyununda yapılan tüm aktivitelerin her an diğer kullanıcılarca ve oyun yönetimince gözetlenebilmesi oyunda gözetleyen iktidar sembollerini oluşturmaktadır. Oyun yöneticileri kullanıcıların hiçbir gizliliğinin kalmasına izin vermemektedir. Oyunun yöneticileri yani iktidarları oyuncuları istedikleri şekilde kontrol edebilmektedir çünkü tüm üst kontrol yetkileri onların elinde bulunmaktadır. Gözetleme artık yalnızca üst yönetimle sınırlı kalmayıp ekranları başındaki tüm kullanıcıları da içermeye başlamıştır. Gözetlemenin limitsizce pek çok kişi tarafından yapılabilmesi oyunda bireysel olarak sahip olabilecek hiçbir mahremiyetin kalmasına meydan vermemektedir. Sanallaşmayla birlikte gözetlemenin de çok kolay bir hale gelmesi gözetimin sınırlarını yıkmaya başlamıştır. Bireylerin oyunda kendilerinin organize ettiği sanal mekanların, aktivitelerin ve her türlü eylemin yirmi dört saatin her anı tüm kullanıcılarca gözetlenebilmesi ve istediklerinde müdahale edilebilmeleri site yönetiminin yanında oyunu gözetleyen izleyicileri de iktidar konumuna getirmektedir.

\section{TARTIŞMA VE SONUÇ}

Günümüz iletişim devrimlerinden biri olarak görülen sosyal medya oyunları gerçek sosyal aktiviteleri sanal bir ortama taşımaktadır. Bu sanal ortamların getirdiği iletişimsel dönüşümler genel literatür taramasının ardından smeet sosyal medya oyunu üzerinden örneklendirilmiştir. Sosyal medya oyunlarının getirdiği kurgusallık ve sanallığın üç boyutlu sanal mekanlara taşınmaya başlaması sanal olan her türlü

eylemi giderek daha fazla gerçek aktiviteye dönüştürmektedir. Smeet sosyal medya oyununun gerçek yaşam aktivitelerinden referans alması nedeniyle bu oyun, kullanıcıların zamanlarının büyük bir bölümüne nüfuz etmektedir. Bu durum gündelik yaşam içersinde sanallaşmayı vazgeçilemez bağımlılıklardan biri haline getirmektedir. Sosyal medya oyunları sanal iletişimde ve sosyalleşmede belirgin bir rol oynamaktadır. Sosyal medya oyunları aynı zamanda farklı yaşam tarzlarının sanal 
ortamda yaşanabilmesinde, güç ve prestijin kazanılan maddi değerler, puanlar ve arkadaş sayısıyla belirlenebilir olmasında, sanal zenginliğin arkadaş edinmek için bir ölçü konumuna gelmesinde, görücü usulü evlilik kültürünün sanal ortama taşınmasında ve hayal dünyasının üç boyutlu görüntüye yansımasında kayda değer bir öneme sahip olmaya başlamıştır. Sosyal medya oyunları kurgusallık ve gerçek yaşam arasında gerçeklik algısını değiştirmektedir. Hayallerin gerçeğe taşındığı bir ortamda oyun kullanıcılarına hem hayallerin hem de gerçek aktivitelerin sanal ortamda kolayca yaşanabilmesi yönünde tatmin etmeye çalışmaktadır. Kullanıcılar bu sanal mekanlarda bir simülasyon evreninin içerisindedirler. Aslına bakıldığında yaşadıkları tüm sanal mekanlar gerçeğin yerini almaya çalışan taklit mecralardır. Oyun kullanıcılarının bu simülasyon evrenine olan bağlılığı görsel imajlarla ve sanal iletişimle birlikte ekranın ardına taşınması temassal yakın mesafede yüzyüze iletişime olan gereksinimi hızla azaltmaktadır. Ekranının ardından her ne kadar çift yönlü bir iletişim sağlansa da bu iletişim kalite ve güvenilirlik yönünden enformasyonun gereken nitelikte kullanılabilmesi bakımından zayıftır. Paylaşılan her türlü iletişimin ve aktivitenin gözetime açık olması oyun kullanıcıları üzerindeki iktidarların kontrol mekanizmalarını arttırmaktadır. Böyle bir ortamda iletişimsel paylaşımların mahremiyeti konusunda herhangi bir gizlilik ve güvenilirlik söz konusu olamamaktadir.

Sosyal medya oyunları zaman-mekan algısını da dönüştürmektedir. Gerçek mekanların yerine tercih edilmeye başlanan sanal mekanlarda sosyal aktivitelerin birçoğu gerçekleştirilmeye başlanmıştır. Bu durum gerçek mekanlarda ve temassal yüzyüze iletişimle sağlanabilen sosyalleşmenin gerçekliğinden uzaklaşmasına sebep olmaktadır. Sanal mekanların sunduğu gerçek yaşamdan referans alınan ya da hayallere hitap eden tüm oyun aktiviteleri boş zamanların büyük bir kısmını doldurarak öncelikle oyuna olan bağlılığı sağlamakta daha sonra ise bir bağımlılık haline gelebilmektedir. Boş zamanların büyük bir kısmının harcanmaya başlandığı bu oyunlar gerçek yaşamsal zamanın içerisinde yer alarak yaşamda öncelikli hale gelmeye başlamıştır. Bu durum sanal mekanların boş zaman dilimi içersinde önemli bir yer işgal ettiğini göstermektedir. Hızla gelişen bu durum bedensel temas ve mesafe ile gerçekleşen yüzyüze iletişimin boş zaman dilimlerinde gerçek mekanlarda 
sürdürülebilmesine yönelik gereksinimi azaltmaktadır. Gerçeklik olgusunun bu şekilde yön değiştirmesi sanallaşmanın giderek daha fazla gerçek yaşama tercih edilmesine neden olacaktır. Oyun kullanıcılarının oyun başında geçirdikleri saatlerin gerçek aktivitelere ayrılan zamanın önüne geçmeye başlaması gerçek aktivitelerin geri plana atılmasına aracılık etmektedir. Sanal mekanlarda geçirilen zaman içerisinde kurulan tüm iletişimler ve etkinlikler artık gerçek yaşamın önemli bir parçası sayılmaktadır. İnsanların en önemli gereksinimlerinden biri olan iletişime ve iletişimle gelişen sosyalleşmeye temassal olarak sağlanacak gerekli zaman ayrılamıyorsa bu durum zamanın da gerçekliğini yitirmeye başladığının bir göstergesidir.

\section{KAYNAKÇA}

ATAY, Tayfun (2005). Kırmızı Bisikletli Çocuk, İstanbul: Radikal Kitap.

BALCI, Şükrü \& AYHAN, Bünyamin (2007). Üniversite Öğrencilerinin İnternet Kullanım ve Doyumları Üzerine Bir Saha Araştırması, Selçuk İletişim Dergisi, Vol: 5, No: 1, 174-197.

BARABASI, Albert Loszlo (2010). Bağlantılar, (Çev: Nurettin Elhüseyni), İstanbul: Optimist Yayınları.

BAUDRİLLARD, Jean (1991). Sessiz Yığınların Gölgesinde ya da Toplumsalın Sonu, (Çev: Oğuz Adanır), İstanbul: Ayrıntı Yayınları.

BAUDRİLLARD, Jean (2003). The Consumer Society, London: Sage Publication.

BAUDRİLLARD, Jean (2004). Tüketim Toplumu, (Çev: Hazal Deliceçaylı ve Ferda Keskin), İstanbul: Ayrıntı Yayınları.

BAUMAN, Zygmunt (2003). Yasa Koyucular ile Yorumcular, (Çev: Kemal Atakay), İstanbul: Metis Yayınları.

BECK, Sade (2004). Internet Ethnography: Online and Offline International Journal of Qualitative Methods Vol: 3, No: 2.

BERMAN, Marshall (2001), Katı Olan Her Şey Buharlaşıyor, (Çev: Ümit Altuğ ve Bülent Peker), İstanbul: İletişim Yayınları. 
BİNARK, Mutlu (2005). Panel Tanıtımı, Sanal Uzamda Oyun Kültürü ve Dijital Oyunlar. inet-tr.org.tr/inetconf11/bildiri/89.pdf, Erişim Tarihi: 05.01.2012

BORDEU, Pierre (1997). Ökonomisches Kapital - Kulturelles Kapital - Soziales Kapital, Die verborgenen Mechanismen der Macht. Schriften zur Politik \& Kultur. Steinrücke M. (der.) içinde. Hamburg: VSA-Verlag. Vol: 1, Page: 4979.

BOYD, D; M. Ellison N. B., (2007). Social Network Sites: Definition, History, and Scholarship, USA: Journal of Computer Mediated Communication. Vol: 13, No: 1 .

BUCKINGAM, Danah (2008). Introducing Identity. Youth, Identity, and Digital Media. Cambridge, MA: The MIT Pres.

BÜYÜKBAYKAL, Ceyda (2008). Küresel Medya Yapılarının Yoğunlaşması, İstanbul Üniversitesi İletişim Fakültesi Dergisi, Sayı: 31. 40-50.

CASTELLS, Manuel (2005). Enformasyon Çağı: Ekonomi, Toplum ve Kültür, A $\breve{g}$ Toplumunun Yükselişi, (Çev: Ebru Kılıç), İstanbul: Bilgi Üniversitesi Yayınları.

CHIP (2011) Focus. Chip Dergisi, www.chip.com.tr/focus Erişim Tarihi: 15.12.2011

CROTEAU, David; HOYNES, William (2003). Media Society: Industries, Images and Audiences Thousand Oaks: Pine Forge Press.

ÇANKAYA, Mehmet Nuri (2010). Dijital Pazarlama Trendleri 2010, İstanbul: MediaCat ve DijitalAge Dergileri Yayını.

DEBORD, Guy (2006). Gösteri Toplumu, (Çev: Aysen Ekmekçi ve Oksan Taşkent). İstanbul: Ayrıntı Yayınları.

DEDEOĞLU, Gözde (2006) Bilişim Toplumu ve Etik Sorunlar, İstanbul: Alfa Akademi.

DİLMEN, Necmi Emel (2007). Yeni Medya Kavramı Çerçevesinde İnternet Günlükleri-Bloglar ve Gazeteciliğe Yansımaları, Marmara İletişim Dergisi, Ocak 2007, Say1: 12, 115. 
DOLGUN, U. (2005). Enformasyon Toplumundan Gözetim Toplumuna, Bursa: Ekin Kitabevi.

DOLGUN, Uğur (2008) Şeffaf Hapishane Gözetim Toplumu, İstanbul: Ötüken Yayınevi.

FOUCAULT, Michel (2006) Hapishanenin Doğuşu, (Çev. Mehmet Ali Kılıçbay), Ankara: İmge Yayınevi.

FOX, Scott (2009). E-Riches 2.0: Next-Generation Marketing Strategies for Making Millions Online, New York: Amacom.

FU, Feng; Liu, Lianghuan; WANG, Long (2007). Empirical Analysis of Online Social Networks in the Age of Web 2.0, Physica A: Statistical Mechanics and its Applications, Vol: 387, No: 2-3, Page: 675-684.

FUNK, Rainer (2006). Ben ve Biz: Postmodern İnsanın Psikanalizi, (Çev: Çağlar Tanyeri), İstanbul:YKY

GRİITTS, Mark (2010). Online Video Gaming: What Should Educational Psychologists Know? Educational Psychology in Practice, Vol: 26, No:1, Page: $35-40$.

GÜRHANI, Nihal (2004). On-Line (Çevrimiçi) Toplumun Doğuşu. www.sinemafanatik.com Erişim Tarihi: 20.09.2011.

HAN, Sam (2010). Theorizing New Media: Reflexivity, Knowledge, and the Web 2.0" Sociological Inquiry. Vol: 80, No: 2.

IŞIK, Metin (2000). İletişimden Kitle İletişimine, Konya: Mikro Yayınları.

JUNIU, Susana (2000). Downshifting:Regaining the Essence of Leisure. Journal of Leisure Research, Vol: 32, Page: 69.

MCLUHAN, Marshall (2001). Global Köy, (Çev.Bahar Öcal Düzgören), İstanbul: Scala Yayıncilık.

KELLNER, Douglas (2001). Popüler Kültür ve Postmodern Kimliklerin İnşası, (Çev. Gülcan Seçkin), İstanbul: Doğu Batı Yayınları. 
KOMITO, Lee; BATES, Jessica (2009). Virtually Local: Social Media and Community Among Polish Nationals in Dublin, Aslib Proceedings: New Information Perspectives, Vol: 61, No:3, Page: 233.

LUHMANN, Niklas (1995). Soziologische Aufklaerung. Cilt II. Opladen: Westdeutscher Verlag.

MARX, Karl (1997). Boş Zaman Üzerine Seçmeler, Cogito. No: 12, 27.

MACMILLAN, John Smith (2006). Eploring Models of Interactivity from Multiple Research Traditions Users Documents and Systems, Handbook of New Media: Socail Shaping and Social Consequences of ICT's.

MİLLER, K.D; FABİAN, F; LIN, S.J. (2009). Strategies For Online Communities, Strategic Management Journal, Vol: 30, No: 3, Page: 305-322.

MİSLOVE, Alan (2007). Measurement and Analysis of Online Social Networks, IMC'07: Proceedings of the 7th Conference on Internet Measurement, Page: 24-26, 31 .

MOHAMMED, Mirghani S.(2007). Knowledge Management Technologies The Triad Of Paradigms in Globalization, Ict, and Knowledge Management Interplay, VINE: The Journal of Information and Knowledge Management Systems, Vol: 37, No:2, Page: 103.

NEUMAN, Marco; Hogan, Deirdre (2005). Semantic Social Network Portal for Collaborative Online Communities. Journal of European Industrial Training, Vol: 29, No: 6, Page: 472.

ÖZARSLAN, Zeynep; Çoban, Barış (2008). Panoptikon Gözün İktidarı, İstanbul: Su Yayınları.

PARKER, Laura (2009). Game Addiction: The Real Story. http://www.gamespot.com/features/6207309/index.html?sid=6207309\&print=1. Erişim Tarihi: 07.11.2011 
PLODERER, Bernd; HOWARD, Steve; THOMAS, Peter (2008). Being Online, Living Offline: The Influence of Social Ties over the Appropriation of Social Network Sites. San Diego, California, USA, Page: 333-342.

POSTER, Mark (1997). Cyberdemocracy: The Internet and the Public Sphere, Holmes. London; New Delhi: Sage Publications.

ROBİNS, Kevin (199). İmaj-Görmenin Kültürü ve Politikasi, (Çev: Nurçay Türkoglu), İstanbul: Ayrıntı Yayınları.

RYAN, Richard (2007). Cause and Impact of Video Games Addiction. All about Health, News, Articles, Discussion. Htpp://ndri.com/article/addictions/internet Erişim Tarihi: 26.11.2012

SANDERS, Michael (2000). MThe Mass Media and The Prevention of Child Behavior Problems. The Journal of Child Psychology and Psychiatry and Allied Disciplines, Vol: 41 No: 7 ,

SENNET, Richard (2009). Yeni Kapitalizmin Kültürü, İstanbul: Ayrıntı Yayınları.

SHİRKY, Clay (2008). Herkes Örgüt, (Çev. Pınar Şiraz), İstanbul: Optimist Yayınları.

SİCİLIA, Maria; PALAZON, Mariola, (2008). Brand Communities on the İnternet, A Case Study of Coca-Cola's Spanish Virtual Community, Corporate Communications: An International Journal, Vol: 13, No: 3, Page: 255-270.

QUALMAN, Erik (2009). Socialnomics: How Social Media Transforms the Way We Live and Do Business. Hoboken, NJ: Wiley.

TAATílA P. Vesa; Soumala, Jyrki; Sıltala, Reijo; Keskinen, Soili (2006). Framework to Study the Social Innovation Networks, European Journal of Innovation Management, Vol: 9, No:3, Page: 312.

TİMISİ, Nilüfer (2003). Yeni İletişim Teknolojileri ve Demokrasi, Ankara: Dost Kitabevi.

WELLMAN, Barry; HAASE Anabel Quan; HAMPTON Keith, K. (2001). Does the Internet İncrease, Decrease, or Supplement Social Capital? Social Networks, 
Participation, and Community Commitment. American Behavioral Scientist, Vol: 45, No: 3, Page: 436-455.

YÜKSEL, Hakan (2006). Online Ölüm Tarikatı, Aktüel Dergisi, No: 27, 22-26.

www.cymg.meb.govtr/modulerprogramlar/arastirma_teknikleri.pdf Erişim Tarihi: 13.02.2012

www.e-psikoloji.com/forum/archive/index, Yeni Bir Madde Bağımlılığı: Bilgisayar Oyunları, Erişim Tarihi: 15.05.2011.

www.mynet.com/blog, Smeet Eğlencenin 3B Dünyas1, Erişim Tarihi: 10.05.2011. 